\title{
講話及資料
}

\section{本邦に於ける揮發油代用燃料事情 (上)}

燃料局技師遠藤一郎

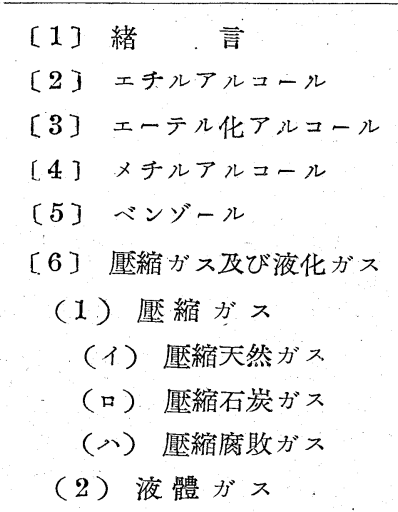

[7]アセチレンガス

(1) アセチレンガスの不純成分

（2）アセチレンガスの爆發性

[8] 菜 炭 ガ ス

[9] 薪炭以外心固體燃料

(1) 草炭

(2) 塵 芥 炭

(3) コーライト

(4) 石炭其の他

〔10]揮發油代用燃料政策に關する所見

\section{[1]緒訔}

自動車用揮發油代用燃料の定義は人に依つて種々異るが, 天然石油，人造石油及び頁岩油亲 の揮發油は源こそ異るが品質全く同一であるから，此處では揮發油代用燃料とは稱さない事と する。剆ち狹義の定義とする。

其の種類は大體次の如きものとならう。

(1) 液體系 エチルアルコール，ェーテル化アルコール，×チルアルコール，ベンジール

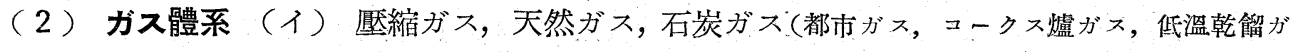
ス), 石油分解ガス，腐敗ガス，溶解アセチレン，（ロ）液化ガス，プロパン，ブタン，ガ ソ ル

（3）固體系 カーバイド (アセチレンガスを發生せしめる), 木材，木炭，草炭，塵芥炭，コー ライト, 石炭, コークス, 亞炭, 亞炭コーライト, カーボナイト, 鋸屑炭, 穴明き豆炭 本邦は既に言ひ古された如く，遺憾乍ら石油貧困國であつて國內生產數量は全需要量の 10 \%にも充たず，他は原油及び製品として海外から輸入して居ると云ふ狀況に在るので，夙に液 體燃料の自給を圖り, 有事の際に備へて置かなくてはならぬと云ふ意見が朝野に㨬頭し, 新に然 料關係行政機構の整備が行はれ，所謂燃料國策の完逐に邁進する事となつたのである。燃料國 
策の根本方針は然料の自給に在るのであり，特に液體燃料に於て然りである。其の方策は人造 石油の製造，國內石油資源の開發，無水アルコールの强制混用，其の他代用燃料の使用獎勵に 依つて國內需要を充足するに在る。然るに昭和 12 年 8 月日支事變勃發後, 戰火山全支に波及 し，本邦としてほ未會有の難局に逢會するに至つた。そして此の聖戰目的逐行の爲め，各種物 資の統制が實施されたが，石油も重要關係物資の一員として登場し，昭和 13 年 3 月 7 日商 工省令第 8 號を以て公布された所の揮發油及び重油販賣取締規則の制定に依り，其の消費は極 度に規正される事になつたのである。其の結果，揮發油代用然料の研究及び使用は急激に活況 を呈するに至つた。

以下各項に涉り揮發油代用然料の研究及び使用狀況を詳述する事とするが，-數字的の發表は 諸般の事情から差控へる事とするから此の點豫め了解を乞ふ第である。又文中意見に涉る部 分は筆者個人の意見であるから此の點も序に御斷りして置く。

$$
\text { [2] チチルアルコール }
$$

エチルアルコール泣單にアルコールとも稱され，普通は農鏟物例へば甘藷，糖蜜を原料とし て製造され，飲料の原料，化學用等て供されて來たが，最近は世界的に揮發油代用燃料として 內燃機關特飞自動車機關に使用されると至つた。アルコールの物理的性質は次の如くである。 師ち 15 度に於ける比重は $0.7946,1$ 䣩當りの總發熱量は 7,140 正カロリー, 1 正の燃燒汇必 要な空氣量は 9 正，1 正當りの氣化潜熱は 210.4 正カロリー，オクタン價は 100 である。

アルコールは之を含水アルコール（普通 94 95\%）の狀態で單體で內燃機關に使用すれば， 揮發油に比較して其の消費量の增加は兔れない。一例を示すと，C.F.R.試驗機關で厴縮比が 4.2〜 5.8 では揮發油の消費量 100 亿對し含水アルコールのそれは 130〜137であつた。其の 上內燃機關の金質を犯したり，クランクケースの潤滑油を稀釋したり，燃料ポンプのダイアフ ラムを犯したり，又は塗料を溶㢦したりするであらう。從つて今直ちに之を自動車然料として 好適なり之推す譯には行かないと思はれる。又之を揮發油に混用する譯にも行かない。其の理 由は混合に依つて以上の缺點は改善されるであらうが，水分に對して安定でなく，假令混和し たとしても些小の水分の混大に依つて二層に分離して了ひ，販賣及び使用上非常なる支障を來 すからである。そてで之を無水として揮發油に混用する事が提唱される。其の理由は例へばア ルコール混大率 10〜20\%の混合燃料であると水分澲しても相當安定であり, 又內燃機關に使 用した場合の出力，燃料消費量等 脢發油單體之同等又はそれ上上 となると云ふ事が各方面の試驗で 實證されて居るからである。アル コールの混大に依る性能の改善は 揮發油のオクタシ價が上畀した事 几因る事が多的。一例を示す之表

\begin{tabular}{|c|c|c|c|}
\hline $\begin{array}{l}\text { アルコール混 } \\
\text { 入率 (容量 } \% \text { ) }\end{array}$ & (15度) & $\begin{array}{l}\text { オクタン價 } \\
\text { (モーター法) }\end{array}$ & 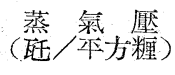 \\
\hline 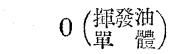 & 0.753 & 60 & 0.69 \\
\hline 10 & 0.756 & 68 & 0.65 \\
\hline 20 & 0.759 & 78 & 0.63 \\
\hline
\end{tabular}

（註）供試揮發油は市販直溜及び分解揮發油の $50: 50$ (容積比)心混合物である。 
示の如くである。

大體以上の樣を理由から石油䝪困國は競つてアルコールを揮發油代用に使用する樣になつた のであるが，周知の如くアルコールは澱粉を主原料とする關係上，澱粉郎ち米，馬鈴署，甘藷 等の生產の少い國では其の混入率も自ら制約され $5 \%$ とか $10 \%$ とかで止めて居る狀態であ る。獨逸，佛蘭西などでは夫及馬鈴署，葡萄などを犧牲とし，其の食糧政策上許し得る最大限 度迄；アルコール化を圖つて届るのであるが，其の秛め一寸でも原料供給の圓滑を缺く之直ち にアルコールの減產が餘儀なくされる。斯程迄に國產燃料の生產に就ては眞劍に考へて居る。

本邦は石油生產額が需要額の $10 \%$ 程度に過ぎないと云ふ情ない狀態ではあるが，澱粉資源 には由來非常に惠まれて居る爲に其の豐富なる潵粉をアルコールに轉化し揮發油代用として使 用せしめる方策が政府に於て企圖されるに到り，其の結果法令に依る揮發油及びアルコールの 强制混用制度が實施される事となつた。そとで昭和 13 年 4 月 1 日には法律第 39 號を以て揮 發油及びアルコール混用法が，同年 4 月 23 日には栜令第 284 號を以て同法施行令が，又同年 4 月 23 日には商工省令第 17 條を以て同法施行規則が公布され，何れも同年 4 月 25 日から內 地及び臺灣に施行された。本法に依れば揮發油の製造，輸入又は移入を業とする者はアルコー 儿混入義務者と定められ，其の工場又は貯油所に於て使用又は引渡される揮發油には原則とし てアルコールを規定量混入しなくてはならないと云ふ事になつて居る。但し輸出用，移出用， 軍用及び特殊用途例へば，航空機の內燃機關用，ゴム工業用，クリーニング用，脂油抽出用等 に供せられる揮發油にはアルコールを混入しなくて良い。揮發油の用途は主に自動車用であり 此の數量は全需要量の 95〜96\%に達して居る。アルコールの混大は主として自動車用を狙 つたのである。混大すべきアルコールは純度 $99.5 \%$ 以上の所謂無水アルコールである。

昭和 13 年 7 月 1 日から愈々アルコールの混入が實施されたが，アルコールの生產が充分 でなかつたにも拘らす何故急速混入を實施しれかと云ふと，全國一般にアルコールを混入する には，一時でも多量のアルコールを眝藏しなくてはならないと云ふ不便がある事と石油消費規 正が同年 5 月から實施された爲め, 急激なる規正の影響を緩和する一方策として生產したら直 ちに混用した方が良いと云ふ樣な事から混大率 $5 \%$ と云ふ低率で然も內燃機關用（航然機の内 燃機關用を除く）揮發油の $25 \%$ 程度任（各月の混入すい゙き揮發油の制合々２0\%を下つてはならない） 混入される事となつたのである。所が何分にもアルコール混大揮發油の取扱に就ては不慣れで もあり又混入率が $5 \%$ と云ふ樣な低率であつた䍃め，水の侵入に 依る分離事故が若干發生し た。そてで分離防止の意味から同年 9 月 1 日以降は同上揮發油の割合に $10 \%$ \%アルール が混入され，越えて本年 4 月 1 日以降は混入率は据置きとし，混大すべき揮發油の割合を 50 \%程度 (各月の混入すべき揮發油の割合は $45 \%$ \%下つてはならない) て廣め, 更に 7 月 1 日から同 混大率で $70 \%$ (各月の割合は $65 \%$ \%をってはならない)の揮發油飞混入されて居る。昭和 13 年 飞混入用として使用されたアルコール數量は約 10,000 竏であつた。政府工場としては年產能 力 2 萬石 (3,600站) の千葉縣稻毛, 茨城縣石岡, 鹿兒島縣出水, 熊本縣肥後大津, 宮崎縣高鍋 の 5 工場が同年中と運轉を開始した， 
14 年中に操業を開始するのは年産 2 萬石 (3,600站) の北海道帶廣, 靜岡縣中泉; 佐賀縣相 知，長崎縣島原，鹿兒島縣鹿，屋，宮崎縣小林の政府 6 工場，特許工場としては熊本縣の昭和 酒造八代工場及び委託工場としては群馬縣の東亞酒精木崎工場並に山口縣の同社三田尻工場， 靑森縣の東北興業八戸工場があり，13 年と運轉を開始しを分を合せると年能力 72,000 站とな る。アルコールの供給に就ては內地丈では充分賄ひ切れないので, 臺灣及び南洋から移入して 其の不足分を補つて居る。臺灣では 13 年 7 月 1 日から特殊用以外の揮發油の全數量にアル コールが混大され，本年 4 月からは $10 \%$ 亿增加された。本島では砂糖工業が盛んであるか ら糖蜜を利用するアルコール製造が主として行はれ，臺灣，明治，大日本，鹽水港，帝國の 5 製糖會社が製造汇當つて居る。劣本島では糖蜜以外飞甘著，キャッサバの增產を圖る事に依つて アルコールの燴產を圖り，餘剩分は內地入移出する豫定であると云ふ。

次々內地に於てアルコールを混入した揮發油を實際販賣使用した場合の成績に就て一寸述へ やう。混大率 $5 \%$ の時には各所のスタンドで分離事故が生起したので實查して見ると，アル コール混入揮發油の取扱ひと當り，スタンド地下槽內の水分を除去して置かなかつたからであ る。當局としても既に此の事あるを豫見し地下槽內部の掃除を勵行する樣に，又給油口の不良 なるものは修繥する樣にと注意して置いたのであるが混用實施直後此事の惹起したのは遺憾で あつた。然し混大率を $10 \%$ 高めてからは取扱ひ及び使用の熟練と相俟つて少しも分離事故 の發生を閆かなくなつそのは喜ばしい事である。アルコール混大揮發油は混入率 $5 \%$ の時でも $10 \% の$ 時でも揮發油單體に比較し，始動性，加速性は殆んぞ同㨾で心配されて居た蒸氣閉塞は 全然生起しなかつた。

只冬期東北地方など寒冷地方に在つては初度の始動及び低速運轉が若干不良である樣を事を 聞いたが，其の後之は冷却水套に溫湯を入れる一寸しを處置に依り，何等支障を生じない事が 明白となつた。燃料沙費量, 出力の點に就ては使用する自動車の機構に依つて異るが, 大體揮發 油單體と大差なく，壓縮比の高い機關例へ壮 6 以上のbのでは點火時期を多少調整する事に依 り消費量は減少し出力は增大すると云ふ結果を得て居る。アルコールは自動車叙料を溶剩する 性質があるが實際問題として之は大した問題にはをらをん。只自動車機關への揮發油裝大唧筒 のダイアフラムが犯されて䅛動不能となり自動車が動かなくなつたと云ふ事故があつたが（本 例は米國製の自動車である。）最近耐アルコール性ダイアフラムが完成したから今後此種の事故は 皆無となら。

大體本邦の自動車は從來米國よりの輸大几俟つ處が大であつたが，米國では揮發油及びアル コールの混用は行はれて居らボ, 其の自動車の機構に就ては少しもアルコールの影響と云ふも のが考慮されて居らなかつね結果，以上の事故を發生したるのと思はれる。ヌアルコールは多 少の水分を含有すると金屬例へ壮鐵,アルミニウム, 輕合金等を腐蝕せしめる性質がある。今迄 の自動車の燃料槽は薄鐵板製である爲に，アルコールと槽の通氣孔から侵入する水分との綜合 作用に依つて腐蝕され，唧筒附屬のスクリンーを鐵銹で詰め揮發油の透入を支障を與へたりす

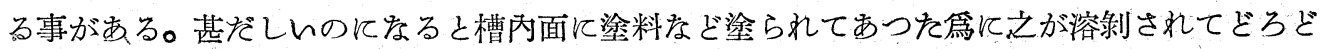


ろとなり唧筒の作用と異變を起さしめれのもある。槽內面及び唧筒內部金具の防銹には亞鉛鍍 金が良好の樣である。最近は自動車製造業者の方でも此の樣な細かい點迄留意され，研究を重 ねて居られる樣であるから安心して可なりである。實際今迄は燃料と內燃機關との連繋が充分 でなかつた樣である。之は獨りアルコール混合燃料の問題のみではをい。問題の核心は內然機 關の壓縮比と燃料オクタン價との關係を廣く一般の使用方面に於て合理的に結び付け，燃料の 有效利用を圖らなくてはならならと云ふ事である。現在アルコールの混入に依つて揮發油の節 約は期待出來をいと云はれて居るが，米國等とは異つて本邦の樣に自動車の使用期間が長い所 では所謂舊車師ち壓縮比の低い車が多數を占めて居る䈆飞，折角アルコールの混大に依つて㩍 發油のオクタン價を高めても少しも有效利用されて居らないからで，之は燃料の有效利用と云 ふ見地から大問題である。米國の自動車は歐洲の自動車に比較して揮發油を倍近くも消費する と云はれて居るが，本邦の自動車工業は米國に學ぶべきではなく，本邦の事情に郎した獨自の 立場で進まねばならない。次にアルコールの單體使用であるが，耐アルコール性ダイアフラム 及び金屬防蝕法の完成した今日，技術的には考虑して良い問題と思はれる。

アルコール單體では始動性, 加速性が良好でなんから始めは揮發油で走り,機關が暖まつたな らばアルコールに切換へる等の操作が必要である。アルコールは氣化潜熱が大きいから混合氣 は冷縮され，吸大效牟を增大し從つて出力を增大し得る利點がある。然し冬期なぼには前述氣 化潜熱の影響に依り，氣化器內の溫度は非常に低くなりアルコールの氣化を阻止し自動車の運 行に支障を來すので, 氣化器の周圍を廢氣の餘熱で適當に加溫する如く簡單な考察を施すと之 もある。單體使用の場合には簡單な 揮發油との切換裝置及び 氣化器豫熱裝置を持つ事て依つ て，無水は勿論の事 $80 \%$ (容量) の含水アルコールでも充分使用出來る。水の多レアルコー ルでは勿論困るが，低廉なる粗製の含水アルコールが使用出來ると云ふ處に興味がある。只此 處で遺憾なのは現在の機關ではアルコールの高オクタン價を利用出來ない事であるが，近い將 來に於て高埾縮比のアルコール專用機關の出現に依つて本問題は解決されるであらう。

然し當分の間單體使用は混入用以外の過剩生產の望まれない事，生產費が揮發油より數倍も 高いと云ふ事，有效利用すべき機關の未完成之云ふ點で可能ではないと思はれる。最後にアル コールの資源として種くのものが擧げられるが，比較的多量であるのに未だ工業化されて居な いタのに亞硫酸パルプの廢液がある。獨逸，瑞典等では製紙工業とアルコール製造工業之は密 接に結び付いて居るとの事であるが, 本邦でも當然さう進むべきである。パルプ廢液からアルコ ールを探取するには先づ廢液中の糖分を醗酵させアルコール化し，此の液を煮詰めれば良いの である。生産費の大部は燃料費である事は直ぐうなづけるであらう。本邦では王子製紙, 北越製 紙等で本事業の工業化を計畫中であるが, 大體 1 孟のパルプから 20〜30 米ガロン (72〜108 立) の含水アルコール (95 容量\%) が生產出來ると云ふ。本邦に 於ける亞硫酸パルプ製造量は昭和

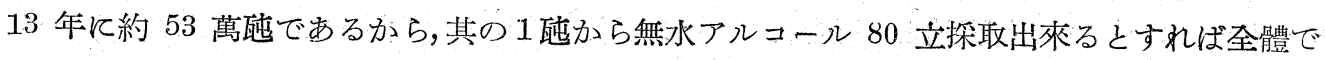
42,400 竏の無水アルコールが得られる譯であるから，却ふ悔り難い數量である。アルコールの 生產が甘諸，糖蜜等の原料問題で惱みつ〉ある現狀隹監み至急工業化すべき新資源であらう。 


\section{[3]エーテル化アルコール}

アルコールは之を單 體として队燃棪然料として使用出來る事は周知の事であるが，何分にも

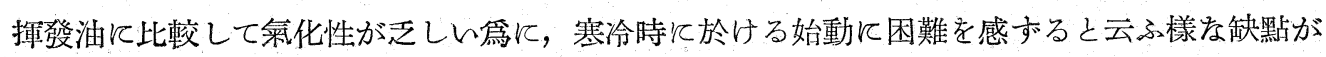
あつた。そてで此の缺點を補ふ鹞には必要時にェーテルを注射するとか又豫め混合して置くと かの方法が良いとされて居た。然し經濟的の問題として考へて見ると之では非常に高價につく ので，始めからエーテルとアルコールとの混合物を製造し自動車用然料としやうとする企てが 行はれ，瑞西國ジュネーヴ市のクリマ氏は同國バーゼル市のブス機械會社と提携し，多年に涉 り研究を行ひ逐に工業的方法を制定した。其の內容样かではないがアルミナとか活性白土等 の脫水觸媒に依り適度を溫度でアルコールを處理すれば，フルコールは脫水されてェーテルを をるものである。本法の利點は含水アルコールを簡單に處理してェーテル化出來ると云ふ點で ある。此のクりマ式のエーテル化アルコール製造裝置は生產能力 1 日當り 100 酏のプラント であると建設費約 15 萬圓であると云ふ。クリマ法に依るエーテル化アルコールをチュークッ 七聯邦工科大學の聯邦材料試驗所で試驗した結果を拔萃すれば烟如くである。

試料の物理化學的試驗

（イ）外 觀 無色透明心流動性液體

（可比重 20 度で 0.781

（八）蒸溜試驗。(A.S.T.M. 法に依る)

溜出溫度 $\begin{cases}\text { 初 } 1 \text { 溜 } & 47 \text { 度 } \\ 50 \% \text { (容量) } & 76 ” \\ 98 \% \text { (容量) } & 81 ”\end{cases}$

殘 渣 $0.2 \%$ (容量)

損 失 $1.8 \%$

（二）低溫に於ける狀態

-40 度迄冷却するも液體は透明て變化しな w。

(木) 蒸氮 壓

り 1ド法で 1 本方粝當り 0.55 䣶。

( $⿴$ ) 化學的成分
(a) 酸含有量
$0.04 \%$ (重量)
(b) 水分含有量
$1.97 \%$ (")
(c) 成 分

エーテル化アルコールを單體で使用する場合は一向て差支へないが，揮發油と混用する時注 意しなくてはならない。少量であると混合せす，二層に分離して支障を來す事が豫想される。 約 $2 \%$ の水分を含有する前記エーテル化アルコールならば少くとも揮發油に $40 \%$ (容量) 以 上混大しなけれ将ならないであらう。此の場合には -25 度で夕溷濁も分離も生起しない。向 モーダーベンジールと揮發油との混合物にエーテル化アルコールを加へを場合にはモーターベ ンゾールが媒溶劑として作用し少量でも混合に支障はない。

例へば揮發油及びベンジール（容量比 1 對 1) ルエーテル化アルコール $20 \%$ (容量)を混合 
すれば -25度に於ても溷濁もしなければ入分離もしない。20 度以上ならばエーテル化アル コールは揮發油と如何なる割合でタ

良く混合する。オクタン價に關する 揮發油との混合效果は右表の如くで ある。

エーテル化アルコールは一寸製造

條件を變化させると，エーテル含有

\begin{tabular}{|c|c|c|c|c|c|}
\hline \multicolumn{2}{|c|}{ 混 } & 合 & 燃 & 料 & ネクタン䨘 \\
\hline \multicolumn{5}{|c|}{ 油發 } & 60 \\
\hline \multicolumn{5}{|c|}{ 揮發油 $+10 \%$ (容量)ニーテル化アルコール } & 64 \\
\hline " & +30 & & & " & 72 \\
\hline " & +50 & & & & 78.5 \\
\hline
\end{tabular}

量の異つた成分が得られる。其の中でェーテル含有量 23 2 $25 \%$ \%場合が最良にして此の場合 のオクタン價は約 90 である。次にエーテル化アルコールを單體使用した場合の一例を擧げて

全荷重 6,850 䣶のトラック麽縮比 43

\begin{tabular}{|c|c|c|c|c|c|}
\hline 燃料の種類 & $\begin{array}{l}\text { 平 均 } \\
\text { 速 度 }\end{array}$ & $\begin{array}{l}\text { 使用量 } \\
\text { 瓦/䊅 }\end{array}$ & $\begin{array}{l}\text { 使 用 量 } \\
\text { 䣶力口リ一粕 }\end{array}$ & $\begin{array}{l}\text { 使用 量 } \\
\text { 䣶カロリ一既 }\end{array}$ & $\begin{array}{l}\text { 使用量 } \\
\text { 八比率 }\end{array}$ \\
\hline 揮 發、油 & 34.8 & 230 & 2,415 & 352 & 1.00 \\
\hline $\begin{array}{l}\text { エーテル化 } \\
\text { アルェール }\end{array}$ & 33.3 & 330 & 2,145 & 313 & 1,43 \\
\hline
\end{tabular}

見や引。

上記の例であると重量 ではエーテル化アルコー ルの方が $43 \%$ 餘計に要 するが，之を容量注換算

すると籸當りの揮發油は 311 竜（20度の比重を 0.74 とする）で，ェーテル化アルコールは 423 䇇 (20 度の比重を 0.78 とす) であるから，容積の比較は揮發油 1 亿對して 1.36 となる。 高壓縮比の機關ではェーテル化アルコールの渻費量壮揮發油の場合より少い。壓縮比が 6 及び 7 の機關では揮發油 $50 \%$ (重量) 及びェーテル化アルコール $50 \%$ の混合物の消費量注揮發 油單體の場合より少い。エーテル化アルコールの利點は始動が良好である事, 相當多量の水分 の混合に對して變化しない事，單體としても揮發油と混合しても使用出來る事である。エーテ ル化アルコールは瑞西及び伊太利で盛んに研究が行はれ，1936 年 12 月 26 日，ル・オート・ マイランド紙上の發表に依ると伊太利交通省は國內諸地方 (マイランド，トリェス，ゼノア等）の 自動車ルエーテル化アルコールの使用を命じをと市る。

本邦に於ても揮發油消費規正の强化に伴ひアルコールの單體使用に關聯し，佾之を效果的な らしめる爲にエーテル化アルコールが研究されるに至つた。大藏省專賣局及び鐵道省が中心之 なつて目下試驗中である。其の試驗臺に依る試驗成績汸別表の如くであるが，大體の使用狀況 を云ふと次の如くである。(イ）ノッキングの傾向はない，(ロ)ベーパーロックはない，(八) 點火時期はガソリンの場合と大差がない（二)空氣量は空氣瓣つ全開に低り，燃料瓣はガソリ ンに比し可成開く必要がある。

上記の試驗結果より出力の點では $25 \%$ ×ーテル化アルコール（無水）が最良で，燃料消費 量の點では $10 \%$ エーテル化アルコール（無水）が $10 \%$ と揮發油 $90 \%$ の混合物が最良で， 揮發油單體飞比し實に $10 \%$ 燃料を節約し得る事が判る。之は現行の如く單に無水アルコー ルを揮發油に混入するよりるェーテル化アルコールとして混入する方が遙かて效果的である事 を意味して居るものである。單體で使用しれ場合は何れも消費量の增加は免れをいのは現在の 機關では止むを得ない所であらう。次にェーテル化アルコールの燃料としての實用性を檢する 
エーテル化アルコール性能試驗成績

\begin{tabular}{|c|c|c|c|c|c|c|c|c|c|c|c|c|c|c|}
\hline & \multirow{5}{*}{ 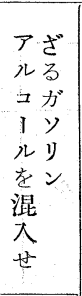 } & \multirow{4}{*}{$\begin{array}{l}\text { 無 } \\
\text { 水 } \\
\supset \\
u \\
\overrightarrow{1} \\
i \\
x\end{array}$} & \multirow{2}{*}{\multicolumn{3}{|c|}{$\begin{array}{c}\text { エーテル化 } \\
\text { アルコール } \\
\text { エーテル含有量 } \\
(\text { (容 積 } \% \text { ) }\end{array}$}} & \multirow{4}{*}{$\mid \begin{array}{c}\text { エ 一テ } \\
ル 20 \% \\
\ulcorner ル コ \\
-ル \\
80 \% \\
\text { 水 } 4 \%\end{array}$} & \multicolumn{7}{|c|}{ エーテル化アルコール, ガソリン混合燃料 } \\
\hline & & & & & & & & \multirow{2}{*}{$\begin{array}{l}10 \% x \\
-\bar{x} \\
\text { 化 } x \\
=-x\end{array}$} & \multicolumn{2}{|c|}{$\begin{array}{l}\simeq ー テ ル \text { 化ア } \\
ル コ ー ル \text { 混入率 }\end{array}$} & \multirow{2}{*}{$\begin{array}{l}20 \% x \\
-\approx \pi \\
1 \text { 开 } \\
z-\pi\end{array}$} & \multicolumn{3}{|c|}{$\begin{array}{l}\text { エーテル化アル } \\
\text { ュール混大率 }\end{array}$} \\
\hline \multirow{3}{*}{\multicolumn{2}{|c|}{ 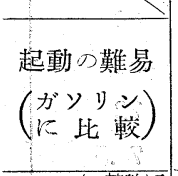 }} & & & & & & & & $10 \%$ & $20 \%$ & & $10 \%$ & $20 \%$ & $25 \%$ \\
\hline & & & & 20 & 25 & 30 & & $\begin{array}{l}\text { ガソ } \\
\text { リン }\end{array}$ & $90 \%$ & $80 \%$ & $\begin{array}{l}\text { ガソ } \\
\text { リン }\end{array}$ & $90 \%$ & $80 \%$ & $75 \%$ \\
\hline & & & 困難 & $\begin{array}{l}\text { 天差 } \\
\text { なし }\end{array}$ & 同 & 同 & 同 & & 同 & 同 & & 同 & 同 & 同 \\
\hline $\begin{array}{l}\text { 發 } \\
\text { 生 }\end{array}$ & 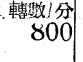 & $26 . ?$ & 25.0 & 25.5 & 26.2 & 25.6 & 25.4 & & 25.2 & 24.5 & . & 24.5 & 25.2 & 25.6 \\
\hline 馬 & 1,000 & 32.6 & 30.8 & 31.4 & 32.4 & 31.8 & 31.2 & & 31.9 & 31.1 & & 30.2 & 31.4 & 32.0 \\
\hline 吕 & 1,400 & 43.5 & 42.5 & 42.7 & 44.0 & 428 & 43.4 & & 42.8 & 41.4 & & 41.0 & 42.7 & 43.0 \\
\hline 㠰 & 1,600 & 48.0 & 47.5 & 48.0 & 48.2 & 48.0 & 48.7 & . & 47.3 & 46.8 & & 45.3 & 47.9 & 47.6 \\
\hline 燃消 & 800 & 0.443 & 0.575 & 0.550 & 0.555 & 0.560 & 0.553 & & 0.412 & 0.447 & & 0.550 & 0.476 & 0.497 \\
\hline 料率 & 1,000 & 0.434 & 0.585 & 0.52 & 0.525 & 0.563 & 0.556 & & 0.414 & 0.388 & & 0.470 & 0.430 & 0.446 \\
\hline 立力 & 1,400 & 0.445 & 0.595 & 0.584 & 0552 & 0.597 & 0.560 & & 0.417 & 0.450 & & 0.460 & 0.438 & 0.445 \\
\hline$\underbrace{\underbrace{n}}$ & 1,600 & 0.475 & 0.650 & 0.610 & 0.582 & 0.625 & 0.560 & & 0.409 & 0.426 & & 0.473 & 0.434 & 0.458 \\
\hline
\end{tabular}

(註) 本表に於けるエーテル化アルコールは製造したものではなく各成分の混合物である。

爲に戶外試驗を行つたが其の成績は次表の如くである。

此の場合には $25 \%$ \%テル化アルコールを使用しをのであるが，然料渻費量は揮發油に比 七僅が $15 \%$ 燴加を示して居るに過ぎす，特に興味があるのは登坂の際に消費量が却つて 少くなると云ふ點である。以上は無水エーテル化アルコールの場合の成績であるが，95\%ア ルコールから製造する含水の場合 (2〜3\%の水分を含む)でもそれと大した相違はなんと思はれ る。生產費を考へて見ると $95 \%$ \%コールから無水アルコールを製造する費用とエーテル化

\begin{tabular}{|c|c|c|c|c|c|c|c|}
\hline \multirow{2}{*}{$=-x$} & \multirow{2}{*}{ 地 名 } & \multirow{2}{*}{$\begin{array}{c}\text { 區間距離 } \\
(\text { 粁) }\end{array}$} & \multicolumn{2}{|c|}{ 燃料消費量 （立） } & \multicolumn{3}{|c|}{$\begin{array}{c}\text { 燃 料 消 費 } \\
\text { (立/彞) }\end{array}$} \\
\hline & & & 揮發 油 & \begin{tabular}{|l|} 
エーテル化 \\
アルコール
\end{tabular} & 揮 發 & 油 & $\begin{array}{l}\text { エーテル化 } \\
\text { アルコール }\end{array}$ \\
\hline \multirow{4}{*}{ 本 坦 路 } & \multirow{2}{*}{$\frac{\text { 品川八ツ山 }}{\text { 保土ケ谷 }}$} & \multirow{2}{*}{25.0} & 5.9 & 7.2 & \multicolumn{2}{|c|}{0.24} & 0.29 \\
\hline & & & \multirow{2}{*}{7.5} & \multirow{2}{*}{10.3} & \multirow{2}{*}{\multicolumn{2}{|c|}{0.21}} & \multirow{2}{*}{0.29} \\
\hline & \multirow{2}{*}{ 大 磯 } & 35.5 & & & & & \\
\hline & & 20.4 & 5.7 & 6.4 & \multicolumn{2}{|c|}{0.28} & 0.31 \\
\hline 登 坂 & 湯 本 & 6.3 & 5.3 & 5.2 & \multicolumn{2}{|c|}{0.84} & 0.82 \\
\hline \multirow{2}{*}{ 降 坂 } & 宮，下 & \multirow{2}{*}{6.0} & \multirow[b]{2}{*}{1.0} & \multirow{2}{*}{0.6} & \multirow{2}{*}{\multicolumn{2}{|c|}{0.17}} & \multirow{2}{*}{0.10} \\
\hline & 湯 本 & & & & & & \\
\hline $\begin{array}{l}\text { 平 坦 路 } \\
\text { (通 計) }\end{array}$ & 保土ヶ谷 & 57.5 & 14.5 & 16.2 & 0.2 & & 0.28 \\
\hline & & 150.7 & 39.9 & 45.9 & 平均 & 0.26 & 0.330 \\
\hline 揮發 & 儿對する & 比率 & 1.00 & 1.15 & 1.0 & & 1.15 \\
\hline
\end{tabular}

アルコールを 製造する費用 とが大體同じ であると云は 礼，又設備費 は脫水の場合 より 8 儿化の方が低 廉であると云 はれる。

從つてアル コールの混大 計畫が完成し た後に於て （揮發油に $20 \%$ 
混入が最終目的）向アルコールの增產が許容される樣を狀況であるならば，文揮發油消費規正の 强化に伴ひ，アルコールに餘剩を生するるならば，アルコールの有效利用の見地から $30 \%$ 之か $40 \%$ とか云ふ混入率は面白くないので，却つてェーテル化して單體使用して了つた方が良い と思はれる。然し揮發油に對するェーテル化アルコールの混入問題は良く檢討しなくてはなら ない。前述の試驗と依ると無水の $10 \%$ エーテル化アルコールを $10 \%$ 容量丈け揮發油に混入 すると揮發油よりも走行能力に於て優秀であるから，合水アルコールより製造される含水エー テル化アルコールの混大（エーテルが或程度媒溶劑の作用をするので揮發油と分離しない）女相當な 成績が期待されるので，含水エーテル化アルコールの混大も一應考虑されて良い問題である。

以上揮發油にエーテル化アルコールを混入すると優秀なる混合燃料となる事は刵つたが，エ ーテル化アルコールの製造に就ては研究の餘地がある。アルコールを部分變性して直接にエー テル化アルコールとする方が良いか，アルコールからェーテルを作つて置いてアルコールに混 合するのが良んかの問題である。前者飞依ると水が相當多量生成するから單體使用は良いか８ 知れないが，揮發油に混入する場合には分離の危險を助長するから良くない。結局混大すると なると脫水を完全にやらなくてはならない。アルコールとェーテルとを别くに混合したもの小 方が此の點で遥かに優れて居る。

执ェーテルの製法であるが，觸媒法に依るよりも硫酸法に依つた方が生產費が低廉であり， 斯樣にしてェーテルを别に製造すればアルコールに對する混合率も自由に變化出來るし，邓ア ルコールを揮發油に混大しを場合よりも消費量が減亦るのであるから多少設備費がかつつても エーテル化設備を增設した方が良いと思はれる。そしてそのエーテル化の方法は硫酸法に依る のが簡單であらう。アルコールの有效利用と云ふ點から云へ壮現在の揮發油及びアルコール混 用法に依るアルコールの混入は之をエーテルとアルー・との混合物に置換しれ方が良いので はないかと思はれる。結局エーテル化アルコーへ人・テテル混合アルコールを單體若くは混

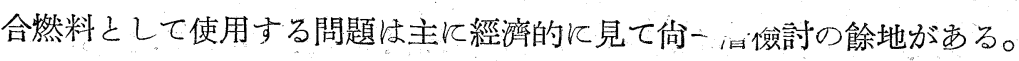

$$
\text { [4] メチルアルュール }
$$

メチルアルコールは，從來は木材乾餾の副產物として採取されて居をが，最近は石炭を原料 として工業的炇成する方法が行はれて居る。本法は石炭, コークスヌはコーライトより永性 ガス反應に依り一酸化炭紊と水素とを製造し之を變性して一酸化炭素と水素との比を 1 對 2 な

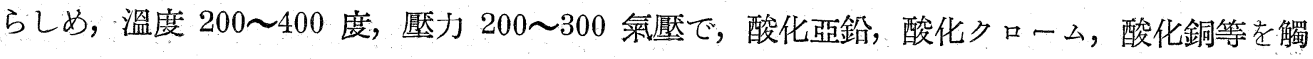
媒として合成せしめるのである。メタノール1能を製造するとは石炭 3〜4 酎が普通である。

本邦に於ては工業試驗所の芝田氏の方法が三井の手依り，初めて山口縣彥島に工業化され た。之が現在の東洋高壓彥島工場である。其の後，合成メタノール事業は各所で工業化される に至つた。其の主なるものは

東洋高壓株式會社 東京メタノール株式會㣂
東京工業試驗所法,クロード法に依るアムモニア合成の副崖 獨逻イー・グー法 
朝蘚石炭王業株式會龍 住友化學工業株式會社: 日本水素工業株式會社 新潟硫酸株式會社
伊太利シソー法

不詳

海 電 法

"クロード法に依るアムモ二ア合戌の副產

メタノールの生產量は昭和 12 年飞於ては約 10,000 站であるが，其の $60 \%$ 以上はフォルマ リン製造用に供せられ，殘餘は染料及び藥品の製造原料，溶齊等に使用せられて居つた。今次 事變の當初はベークライト合成に必要をる石炭酸の不足を來した爲めベークライトの減産を招 來し，他の原料たるフォルマリンの過剩, 延いてはメタノールの生產過剩を來したのであつた。 然ると事變の進展するに從ひ，物資の不足を來し，其の結果代用品工業の勃興を促進し，フ ルマリンを原料とする各種の樹脂等の需要が激增し，今度は品不足の聲を聞くに至つた。揮發 油代用燃料として一部自動車用に供せられて居るのも一原因の樣である。メタソールの動力用 としての性能の一端を云へば，熱量は 1 然に付を 5,210 正カロリー，オクタン價は 98 ，蒸 發潜熱は 1 正化付き 265 正カロリーであり，熱量から云ふと揮發油の約牛分位しかないが，オ クタン價が高レから，高壓縮比の穖關に使用すると此の方で熱效率を補へる譯で，單體として b，揮發油との混合物としても使用出來る。

メタノールのオクタン價に就ては次の樣な實驗例がある。メタノール單體では，潜熱が大で あ方爲め，空氣とメタノールとの混合氣の溫度は之を C.F.R. 機關のオクタン價測定の際の標 準溫度に保持する事が出來ない爲と，揮發油と充分混和する事が出來ない第にオクタン價既知 の揮發油て他の液體燃料を混じ，之にメタノールを混合して測定を實施しなくてはならない。 一例を擧げると，小倉石油株式會社製の航空 3 號揮發油 $70 \%$ \%ベン゙ール $30 \%$ 加へた混 合揮發油（オクタン價 71.9）にメタノール，エタソール丈はモーターベンゾールを各 $10 \%$ 混合 した時のオクタン價上景の割合は, メタノールはベンゾールに比較し約 $6.4 \%$ 大きく，エタ， ール飞比較し約 $0.5 \%$ 小さく，20\%混合の場合にはメタノールはベンゾールに比較して 10.8 \%大きく，エタノールと同等となり，30\%ではベンジールに比較して約 $11.1 \%$ 大をく，エタ ノールとは同等である。結局メタ；ールのアンチうック性は通常大手し得る液體燃料の中で最 高に位するものである。

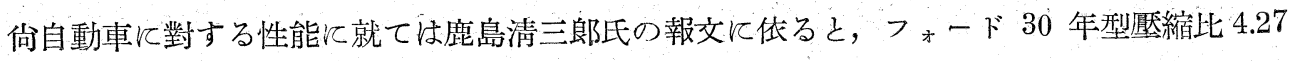
の自動車にメタノール混合氣を豫熱する裝置を取附け，メタノール單體で走行試驗を實施した 處，平坦路に於ける燃料渻費量は揮發油 100 飞對しメタノール 149 であり，登坂路では揮發 油 100 飞對しメタノール 130.9 であつた。結局メタノールは負荷のかよつた場合の方が優秀 である事が判つた。他の實驗例に依ると本地に於ける消費量は揮發油の1.9 倍である事，そし て C.F.R. 機關で厴縮比 5 なる場合には揮發油の約 1.8 倍で，壓縮比を增加する場合には其の 消費量を若干減少する事を認めを。獨逸に於ては石油の輸大又は製造を業とするものは獨逸專 賣局よりメタノール大りのアルコールを購大する義務を負はされた。郎ち 1938 年 8 月 31 日附 告示は重量で $13 \%$ \%然料アルコール(メタ)ール垎混入)を混大し，殘部の揮發油にはベンゾー ルを混大すべき事になつて居る。然し本邦に於てはメタノールの强制混用制度は行はれて居な 
レ。近い将來に於てメタノール工業がブタノールの生產を主とする方向に轉換すれば，副產物 として低廉にして多量のメタノールが生產される事となるから，其の䁱には單體としても亦混 用しても有力なる代用燃料としての地步を確立する事となるであらう。現在の需給狀況では生 產費に於ても量的見地からしても，代用然料としての實用性快難色があると思はれる。

$$
\text { [5] ヘンン゙ール }
$$

-. 純ベンゾールは比重 0.879 (15度に於て)，沸點 80 度，凝固點 6 度，發熱量 1 㴙沉付き 10,026 瓦カロリー，オクタン價 97 で,發熱量は單位重量では揮發油より劣るが，單位容積では約 13 高く，オクタン價も遥かれ高い。從來はモーターベンゾールを揮發油に 10〜30\%混合して航 空燃料に使用して居たが,ベンゾールの混合に依るオクタン價の增加は計算值より低いし, 又此 の混合燃料に對する四ェチル鉛の效果も少く且つ凝固點が高い禡に今日ではベンジールは適當 ではないとされて居る。然し自動車用としてアルコールと共に揮發油に混用する事は增熱並に アルコールの分離防止に相當效果があるし，又戰時には主として懪藥に轉用されると云ふ長所 がある。モーターベンゾールが自動車用として使用されたのは歐洲大戰中で，英國が最初で， 次は佛蘭西であつた。佛蘭西では 1925 年に，ベンゾール包收に關する大統領令に依り巴里の ガス製造所はベンジールの包收を强制された。獨逸でタ 1926 年飞 1 万年間 200 萬立方米以 上のガスを製造し且つ其のガス 1 立方米に付きベンジールヌはトルオールが 15 瓦以上存在し て居る時は法律に依り，强制的に旬收すべき事が規定された。獨逸では近年石炭乾餾事業の發 達に件ひベンゾール回收に努めた結果, 昭和 13 年には其の產額は 40 萬醐に達した。

伊太利でも1926 年法令に依り，商工大臣が指定したガス製造所にして1 ケ年 200 萬立方 米以上のガスを製造する工場に對して特別を契約を除き，1 立方米の石炭ガスからベンジール 又はトルオール生產に必要なる輕油を少くとも15 瓦探取しないガスは販賣してはならない事 が明示され，更に乾餾副產タールは蒸溜してベンジール輕油の探取方を强制され，生のタールの 販賣及び使用は禁止されて居り，又國立のタール蒸溜所に販賣する場合には夕ール生産者は自 己の工場で蒸溜する事を要しない事を規定されて居る。本邦では法令の發動てそ見ないが商工

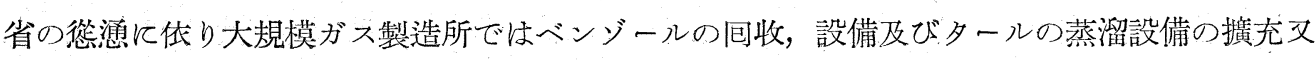
は新設沃努めつ小ある。石炭から包收し得るベンジール量は乾餾爐の型式に依つて異るが，本 邦の例ではガスからの場合には原料炭1 䣩飞對し 0.8 〜 $1.3 \%$ (重量) で，タールからの場合に は・約 $0.05 \%$ (重量)である。

ベンゾールの包收法には洗涤法と吸着法とがある。洗桬法はガス中のベンゾールを吸收油 (輕油)で洗滌吸收せしめるものであり，吸着法はガス中のベンゾール蒸氣を活性炭素で吸着せ しめ，水蒸氣を吹き込んで吸着ベンゾールを放出せしめる方法である。本邦では從來殆に゙洗滌

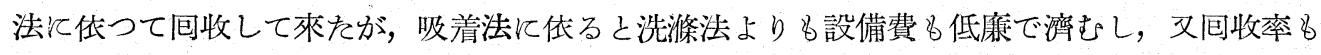
10〜20\%方增加する利益があるので，東京瓦斯，東邦瓦斯，京都瓦斯，京濱コークスの諸社 は本法を探用し，工場建設計畫を進めて居る。本邦內地昭和 13 年に於けるベンジールの推定 
生產高は約 5 萬酏で未包收の分郎ちガス事業，製鐵事業，コークス製造業者にして年間 1 萬䣩 以上の石炭を處理する回收未着手の8のより新に回收し得るベンゾール數量約 1 萬醐を併せる と，約 6 萬酏である。現在既儿回收して居る8のは (洗滌法に依り) 日本製鐵，三井鑛山，日 本化成，東京瓦斯，東邦瓦斯，大阪瓦斯，神戶瓦斯等である。滿洲で注昭和製鋼，滿洲化學工 業等の大口生産者がある。

ベンゾールの他の製法としては

(1) アセチレンを重合する法:

(2)オレフィン類郎ちエチレン，プロピレン，ブチレン等を高溫重合する法

（3）メタンを直接高溫處理するか又はメタンを分解してアセチレンとなし重合する法

(4) 高溫タールを高溫水素添加する法

上記 4 法の中で現在事業化して居るのは（1）の方法である。本法は活性炭，コークス，耐火 煉瓦，磁器片の如き安價をる觸媒を使用し，650 度內外の溫度でアセチレンガスを通じ，之を タール化せしめるのである。此のタールの成分は輕質油に富み，芳香族郎ちベンジール及びト ルオールは約 50 \%以上に達する。カーバイド 1 再からは普通約 280 立のアセチレンガスを 發生し，此の重合に依り 280 瓦の重合油を得る。ベンゾール類の收率を 50 \%とすれば 140

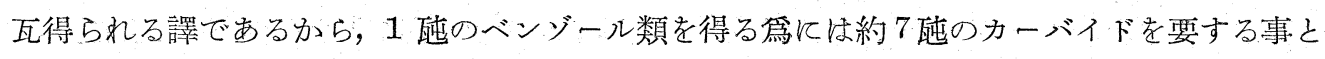
なる譯である。日本カーバイド工業株式會社では工業試驗所法に據り富山縣魚津に 300 赸プラ

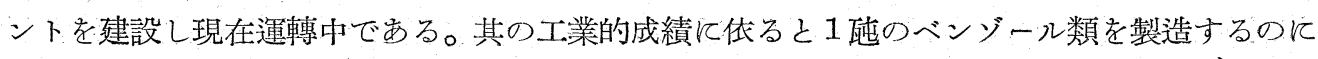
カーバイド 10 䣩以上を要するとの事である。本ベンゾール合成事業はカーバイドの供給確保 困難と生產費の高價に依り前途多難であり，從つて本法に依る增產恃差當り望み得ないであら 30

（3）の後者の方法は天然ガスを減厴下で電氣火花に依り分解し，アセチレンとなし，アルコ ール水を使用してアセチレンを精製濃縮し，次に重合爐で加熱重合せしめ，ベンゾールを成分 とする液體を製造するのである。天然ガスの分解に依つて生成する水素及びカーボンブラック は夫及硫安及び顏料原料として利用すればベンゾール製造工業の採算は有利となる。本法に關 しては海軍然料滺藤尾誓氏の研究があり，日本鑛業は之を引繼ざ，臺灣竹東油田の研究所で目 下工業化の研究中である。

ベンゾール類は燃料として文爆藥原料として緊要不可缺の資材であるから極力其の增產に努 め，平時々揮發油と混用せしめ，戰時には爆藥の用に供すべく適當な措置を講するる事がベンゾ 一ル資源の貧弱なる本邦として珡急の要務である。(未完) 